\title{
Local preferences and the allocation of attention in equity-based crowdfunding
}

\author{
Marco Bade ${ }^{1} \cdot$ Martin Walther $^{1}$
}

Received: 1 April 2020 / Accepted: 2 December 2020 / Published online: 3 February 2021

(c) The Author(s) 2021

\begin{abstract}
This study examines drivers of investment probability in equity-based crowdfunding using a hand-collected and comprehensive data set from a well-established platform. The analysis confirms several effects that have been reported in the recent literature on other crowdfunding markets. Extending recent research, we study moderators of local preferences of investors. Novel to the literature, we find that (1) local preferences are more pronounced in campaigns of younger ventures, (2) herding-like behaviour is stronger in local campaigns and (3) local investors are more responsive to updates posted by entrepreneurs, compared to non-locals. Our results suggest that investors allocate more attention to campaigns for which they have information advantages, such as local campaigns, due to their limited capacity to process information. Such behaviour may eventually amplify information asymmetry and local preferences. Our findings have practical implications for entrepreneurs, investors and platforms.
\end{abstract}

Keywords Individual investor behaviour - Local preferences · Attention allocation · Limited information processing capacity $\cdot$ Equity-based crowdfunding

JEL Classification D83 · G11 $\cdot$ L26 · M13

\section{Introduction}

Recently, alternative forms of business financing, such as equity-based crowdfunding, have emerged and are on the rise. In particular, the transaction value of equitybased crowdfunding in Europe (excluding the UK) has grown from 63.1 million

Marco Bade

marco.bade@tu-berlin.de

Martin Walther

martin.walther@tu-berlin.de

1 Chair of Finance and Investment, Technische Universitaet Berlin, Sec. H 64, Straße des 17. Juni 135, 10623 Berlin, Germany 
EUR in 2012 to 278.1 million EUR in 2018 (Statista 2020). Therefore, the topic continuously gains attention of researchers. Equity-based crowdfunding is defined as "[...] a form of financing in which entrepreneurs make an open call to sell a specified amount of equity or bond-like shares in a company on the Internet, hoping to attract a large group of investors" (Ahlers et al. 2015, p. 955).

Remarkably, recent research confirms that crowdfunders tend to invest in ventures which are located nearby. The overrepresentation of local assets in a portfolio is commonly referred to as "home bias" or "local bias". ${ }^{1}$ In the following, we refer to "local preference" as a higher probability of investors to invest in local ventures. Since French and Poterba (1991), a steadily growing stream of literature has dealt with the phenomenon of home bias in many different contexts, for example, international trade (Wolf 2000; Hillberry and Hummels 2003; Disdier and Head 2008) and financial investment decisions (Cooper and Kaplanis 1994; Coval and Moskowitz 1999; Stuart and Sorenson 2003; Ahearne et al. 2004; Karlsson and Nordén 2007; Graham et al. 2009; Dziuda and Mondria 2012).

In the crowdfunding context, Agrawal et al. (2015) examine the prepurchase platform "SellaBand" that connects musicians with funders. Compared to distant funders, local funders appear to be less responsive to information about the cumulative investments in an artist. However, this distance-related effect is explained by funders who fall into the category "friends and family". According to Hornuf et al. (2020), the local bias is also present on the German equity-crowdfunding platform "Innovestment". Likewise, in the context of equity-based crowdfunding, based on data from the "ASSOB" equity-based crowdfunding platform, Guenther et al. (2018) show that geographic distance is negatively correlated with investment probability for home country investors. In contrast, overseas investors are not sensitive to distance. By employing a quasi-experimental design, Lin and Viswanathan (2016) investigate the mechanisms behind local bias on a virtual peer-to-peer-lending marketplace called "Prosper". They find evidence that local bias exists in peer-to-peer lending. They argue that economic-based explanations cannot fully explain local bias. Instead, behavioural reasons, such as the familiarity bias, drive this phenomenon at least partially.

We aim to contribute to this stream of literature in two ways. First, we test whether recent findings on drivers of investment decisions in crowdfunding can be confirmed using a unique hand-collected data set from a well-established platform and a modified dyadic approach based on Agrawal et al. (2015). Second and new to the literature, we explore interactions between these drivers and geographic proximity, in order to examine the explanation of local preferences related to asymmetric information, in particular the limited information processing capacity and attention allocation of investors (see, e.g., Sims 2003; van Nieuwerburgh and Veldkamp 2009; Mondria and Wu 2010).

For this purpose, we investigate several hypotheses that are expected to provide novel insights. First, we test how the degree of publicly available information

\footnotetext{
1 Note that the first relates to local preferences across borders and the second refers to local preferences within countries.
} 
(proxied by venture age) moderates local preferences. It seems natural to assume that locals' information advantages are particularly pronounced in younger ventures. Therefore, investor' preference to invest in local campaigns might be stronger the younger the venture. In our analysis, we aim to substantiate this intuition. Second, we examine whether locals or non-locals are more responsive to signals (posted updates) by presumably better-informed entrepreneurs. Third, we test which type of investor is more responsive to signals from peer investors (recent previous investments). On the one hand, it seems intuitive that signalling by entrepreneurs or by peer investors alleviates asymmetric information between locals and non-locals and thus reduces local preferences. On the other hand, however, if investors pay more attention to signals concerning local campaigns, as is suggested by the attentionallocation theory, it is conceivable that information asymmetry and local preferences get reinforced by updates or recent previous investments. Our study aims to help clarifying this puzzle.

The results of our study confirm the existence of local preferences in equity-based crowdfunding. Consistent with recent research, we find indication for L-shaped investment patterns (Hornuf and Schwienbacher 2018), herding-like behaviour (e.g., Hornuf and Schwienbacher 2018; Vismara 2018; Walther and Bade 2020) and a positive effect of recent updates (Block et al. 2018). Remarkably, the more updates have already been posted, the weaker the positive effect of updates. Novel to the literature, we find that, first, local preferences of investors decrease in venture age. Second, herding-like behaviour is more pronounced among local investors. Third, compared to non-local investors, locals are more responsive to updates posted by entrepreneurs. We link these new empirical findings to investors' limited capacity to process information and argue that our results are consistent with the related attention-allocation-based explanation of local preferences.

The remainder of the paper is organized as follows: Sect. 2 presents the theory on local preferences. Section 3 develops our hypotheses. In Sect. 4, we explain the empirical setting and the sample construction. Section 5 presents our econometric model. Subsequently, in Sect. 6, we present the results. Section 7 discusses the results of our analysis. Section 8 concludes the paper.

\section{Theory on local preferences}

Table 1 provides on overview of explanations of home bias, local bias or local preferences in the non-crowdfunding-related literature. The table is structured as follows: rows represent reasons that may explain the phenomenon. The first column lists exemplary studies focusing on the respective explanation from the non-crowdfunding-related literature. The second column assesses the potential relevance of each explanation for equity-based crowdfunding. The last column justifies why it is important to investigate the respective explanation in the context of local preferences in equity-based crowdfunding. In the following subsections, we present the theoretical background of our study based on a comprehensive literature review, in which we refer to this table. Note that for the sake of completeness the table also includes literature on behavioural explanations, which we do not test in this study. 


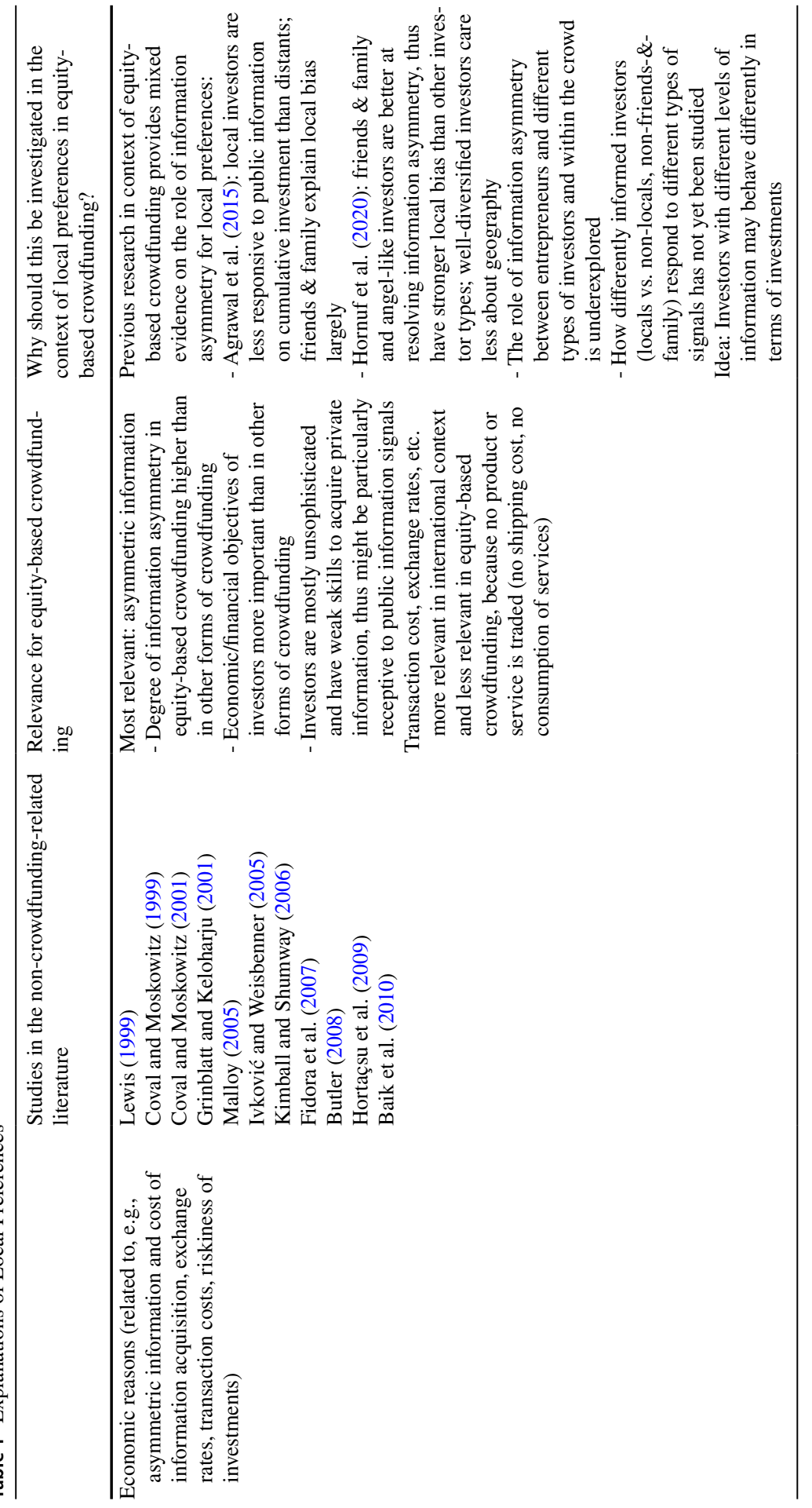




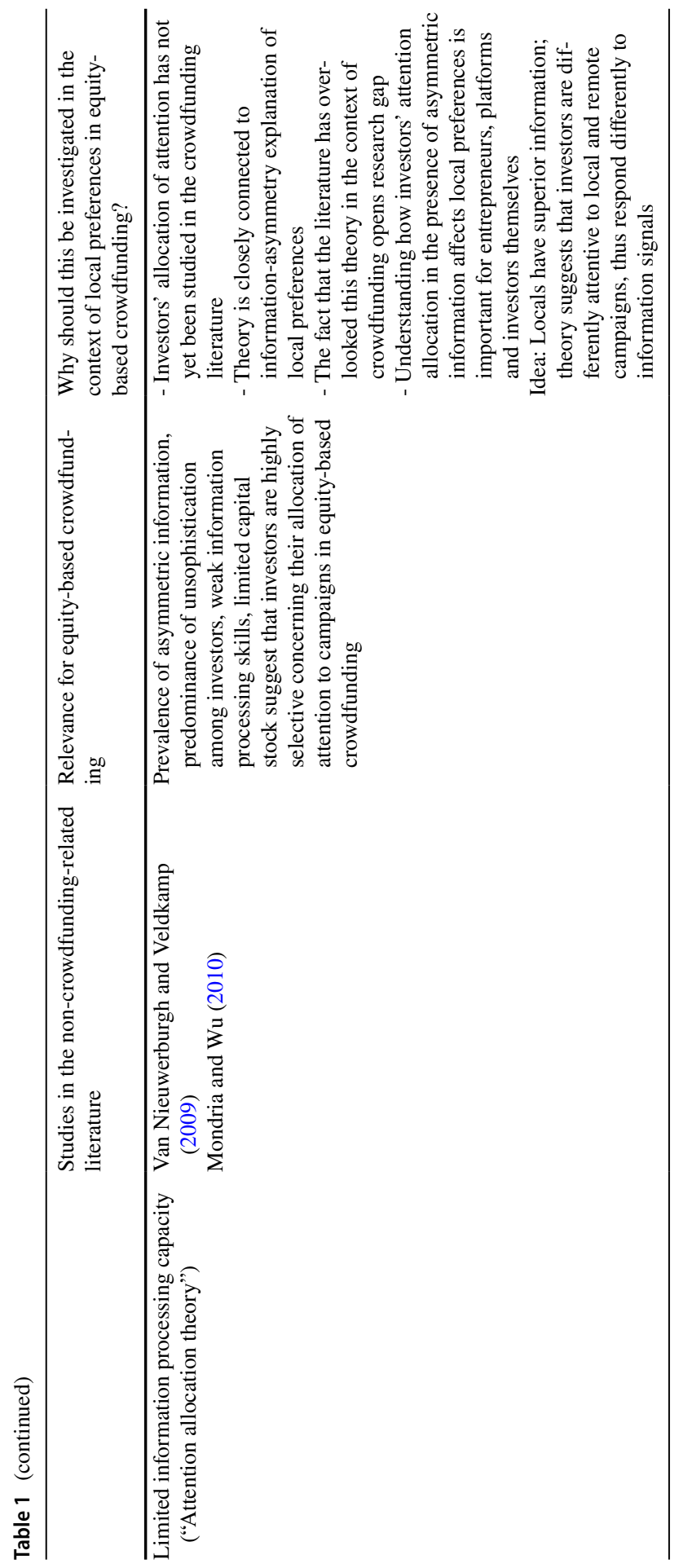




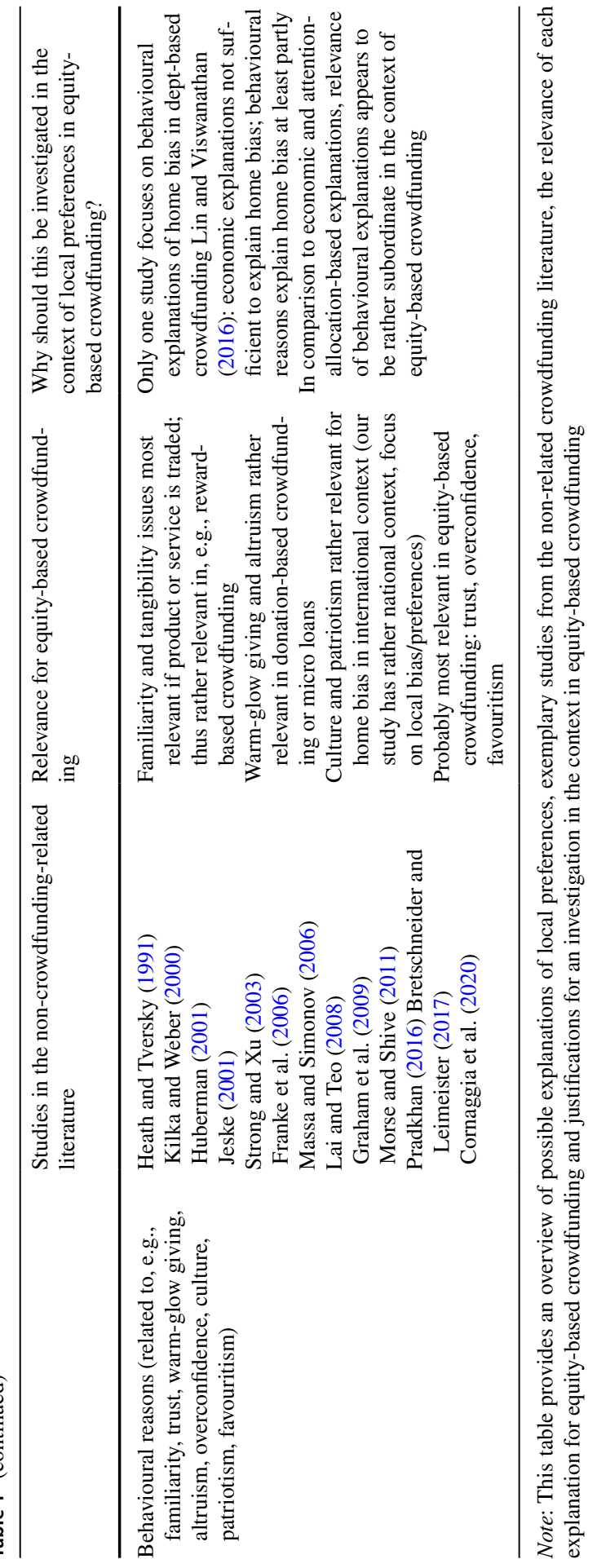




\subsection{Economic-based explanations of local preferences}

Many economists justify the role of distance with economic arguments. For example, Fidora et al. (2007) explain portfolio home bias with real exchange rate volatility. Most of the literature, however, focuses on the importance of information frictions and transactions costs. Transactions on markets typically cause transaction costs that include costs of, for example, shipping, cultural differences, information acquisition, or informational disadvantage because of geographical distance (e.g., Lewis 1999; Grinblatt and Keloharju 2001). This implies that there are local advantages related to search and monitoring. Local investors can make use of various channels to acquire important information about a company. For example, they can assess firm quality by visiting a store. They can directly contact the company, its employees, managers, suppliers and other business partners to obtain first-hand information. In addition, they may obtain important information from the local media or from personal contacts to local executives. These channels provide them with an information advantage over distant investors who do not have access to such channels (Coval and Moskowitz 1999; 2001; Kimball and Shumway 2006).

Malloy (2005) shows that local analysts provide more accurate forecasts than remote analysts, suggesting that local analysts have information advantages translating into better performance. Ivković and Weisbenner (2005) find that local investments of households yield higher returns than non-local investments. For investments in smaller companies, where private information advantages should be even more important, the asymmetry is greater. This suggests that local investors indeed have information advantages and exploit local knowledge. Baik et al. (2010) show that local institutional investors, who are considered informed investors, execute more profitable trades than non-local institutional investors. This suggests that geographic proximity allows better access to superior information.

Unlike institutional investors or professional analysts, crowdfunders are typically less sophisticated and invest smaller amounts. Their ability to acquire private information are rather weak. Furthermore, crowdfunding involves the investment of private assets rather than corporate funds. Therefore, crowd investors typically have limited capital stocks to invest. Consequently, they need to be selective regarding their investments and to rely on publicly available online information. This raises the question whether unsophisticated investors also have local preferences caused by asymmetric information. The literature on home bias focuses mainly on large and sophisticated investors, such as US money managers (Coval and Moskowitz 1999), venture capitalists (Stuart and Sorenson 2003), large custodians and large institutional investors (Ahearne et al. 2004), mutual funds (Karlsson and Nordén 2007) and fund managers (Dziuda and Mondria 2012).

Note that the studies mentioned above focus on offline investments. It is conceivable that in online markets frictions related to asymmetric information can be overcome. Remarkably, however, Hortaçsu et al. (2009) show that on the online products market "eBay", transactions are still more likely to occur between buyers and sellers from the same area. Geographical distance between buyers and sellers can still play a role because of shipping charges, localized consumption of the goods (e.g., event tickets) and the possibility of direct contract enforcement. In equity-based 
crowdfunding, however, no products or services are traded. Therefore, transaction costs related to shipping and local consumption should play a minor role. Instead, financial objectives are more prevalent in equity-based crowdfunding. Thus, investors in equity-based crowdfunding might behave differently compared to consumers or funders in, for example, reward-based or donation-based crowdfunding campaigns, as information on venture quality might be more important than, for example, familiarity with a product or service. In the next subsection, we will discuss the role of asymmetric information in crowdfunding, especially equity-based crowdfunding, from a theoretical angle.

\subsection{Asymmetric information in crowdfunding}

Asymmetric information is a highly relevant problem in crowdfunding, particularly in equity-based crowdfunding. Hemer (2011) and Ahlers et al. (2015) emphasize that the degrees of complexity and information asymmetry in equity-based crowdfunding are higher than in all other forms of crowdfunding. Agrawal et al. (2014) conceptually discuss the prevalence of information asymmetry in crowdfunding markets, especially in the case of equity-based crowdfunding. According to some theoretical studies, asymmetric information matters for entrepreneurs' choice of financing. Belleflamme et al. (2014) demonstrate that asymmetric information changes financing possibilities in both reward-based and profit-sharing-based (equity-based) crowdfunding. They argue that observing previous pledges and learning from each other about campaign quality may help overcome information frictions. While Belleflamme et al. (2014) find that asymmetric information favours equity-based crowdfunding, Miglo and Miglo (2019) theoretically show that entrepreneurs with high-quality projects prefer reward-based crowdfunding. Miglo (2020) considers a model in which an entrepreneur chooses between different types of crowdfunding. The model contains elements of asymmetric information and behavioural finance and predicts that overconfident entrepreneurs prefer equity-based crowdfunding because they learn from the sales of shares before producing the products or because crowdfunders strategically anticipate entrepreneurial behaviour. According to Miglo (2020), reward-based crowdfunding is neither subject to learning nor to strategic interaction between entrepreneurs and crowdfunders. In contrast, Chakraborty and Swinney (2020) theoretically examine how an entrepreneur can use the campaign design in reward-based crowdfunding to signal project quality to funders. They demonstrate that setting a campaign target that is above the one that would be optimal with full information enables the entrepreneur to signal high quality.

These studies emphasize the importance of considering asymmetric information in crowdfunding, especially in equity-based crowdfunding. Note that, however, most of the theoretical studies on crowdfunding consider asymmetric information between entrepreneurs and investors but not within the crowd. Our study also focuses on the latter. Therefore, this study aims to contribute to the theoretical literature on crowdfunding, as our results may provide a basis for future theoretical research.

Additionally, while online markets, such as crowdfunding platforms, enable entrepreneurs to tap a greater audience, they can exacerbate asymmetric information 
because ventures are typically young and the amount of publicly available information is limited (Lin et al. 2013). Some investors may have private information due to social or geographical proximity. Thus, investors, such as friends and family or local investors, may have superior information from entrepreneurs, local media or local communities compared to remote investors who had no contact to the venture before the crowdfunding campaign. Such heterogeneities among investors are another particularity of crowdfunding. This stresses the importance to consider asymmetric information between entrepreneurs and investors as well as within the crowd of investors, when examining local preferences in crowdfunding.

\subsection{Limited capacity to process information and the allocation of attention}

Related to asymmetric information, another stream of research dealing with local preferences in financial markets is based on Sims' (2003) theory on rational inattention, which makes use of Kahneman's (1973) finding that attention is a limited cognitive resource.gabaix and Laibson (2003) as well as Gabaix et al. (2003) show that this theory plays a role in economic settings by analysing agents' allocation of thinking time when choosing consumption goods from a wide selection of goods. Peng and Xiong (2006) study the effects of investors' allocation of attention on asset-price dynamics. They find evidence for so-called "category learning behaviour" which means that investors pay more attention to information on markets and industry than to firm-specific information.

Van Nieuwerburgh and Veldkamp (2009) theoretically demonstrate that investors choose to allocate more attention to assets for which they already have an information advantage. Therefore, they reinforce information asymmetries instead of reducing their own information disadvantages. The authors further show that small information advantages of local investors are sufficient to explain home bias of larger magnitude. In Mondria and Wu's (2010) model, investors reduce the uncertainty of their portfolio by learning information about the economy's state. However, due to their limited capacity to process information, they decide to allocate more attention to domestic assets. As a result, their portfolios consist mostly of domestic assets. This tendency towards domestic assets is amplified by information advantages of locals. Moreover, an increasing demand for domestic assets feeds back into investors' incentive to learn about these assets.

Regarding the crowdfunding context, this implies that investors might allocate more attention to campaigns of ventures for which they may have information advantages, such as local ones. Thus, we expect investment behaviour to differ between local and non-local investors. The attention-allocation theory represents the basis for our study and will be used in the further course of this paper to substantiate the expected effects.

\subsection{Prior research on local preferences in equity-based crowdfunding}

Agrawal et al. (2015) were the first to find that geography matters for crowdfunding investments. They attribute this to asymmetric information. However, they further find 
that friends and family, who may have information advantages and live proximate to the campaign, explain the differences in the behaviour between local and distant funders to a large extent. Guenther et al. (2018) find that home-country investors in Australia are sensitive to distance. This may be explained by increasing information asymmetry with increasing distance. However, they provide no evidence on this explanation. In contrast, overseas investors are not sensitive to distance. This may be because overseas investors are unable to directly assess venture quality due to traveling costs anyway. Consequently, they care less about distance. Recently, Hornuf et al. (2020) argue that angel-like investors and friends and family have stronger local bias because they are better at resolving information asymmetry. In contrast, well-diversified investors care less about geography.

These studies provide varying results regarding the relevance of asymmetric information for local preferences in equity-based crowdfunding (see also Table 1, first row). For instance, while Agrawal et al. (2015) find that local bias is explained by friends and family and social ties between entrepreneurs and investors, Hornuf et al. (2020) find that local bias also exists among investors who are not friends and family of the entrepreneur. They attribute this to different levels of transaction cost related to screening and monitoring incurred by different types of investors, such as angel-like, experienced and friends-and-family investors. However, such investor types are not observable on most crowdfunding platforms and a categorization of investors based on ad-hoc assumptions could lead to biased results. Therefore, we follow the approach of Agrawal et al. (2015) and only distinguish between local and non-local investors, which is an observable characteristic. Moreover, this categorization appears to be most suitable to proxy for asymmetric information. Additionally, we consider friends and family, because previous research has shown that this group is most important to consider in the context of crowdfunding.

Furthermore, how differently informed investors react to relevant information and signals from local or remote ventures, respectively, is an underexplored field. In particular, the attention allocation theory has not yet been considered in the crowdfunding context. We argue that this is an important field of investigation because the resources of investors in equity-based crowdfunding are likely to be particularly scarce, as they are usually unsophisticated. The limited capacity to process information in the presence of information asymmetry makes investors pay even more attention to local campaigns for which they already have information advantages. This may make them more responsive to information and signals on these campaigns and may reinforce both local preferences and information asymmetry. In a way, this rationale is in contrast to Agrawal et al.'s (2015) result that distant investors are more responsive to public information. In the light of the attention allocation theory, geographic proximity may moderate other drivers of investments, such as venture age, previous investments and updates (see also Table 1, second row). This will be the focus of our hypotheses. 


\section{Hypotheses}

In view of the studies mentioned above, we need to carefully consider information asymmetry in the context of our equity-based crowdfunding study. Unfortunately, however, information asymmetry is not directly observable. This requires us to use applicable proxies. In line with the knowledge from home bias literature, investors may have information advantages regarding local ventures. This advantage is likely to be larger for ventures with less publicly available information, such as younger ventures (see, e.g. Lu et al., 2010). Nguyen et al. (2019) demonstrate that investors in fact delay their investments in equity crowdfunding campaigns expecting to receive more information in the meantime. The idea is that the degree of asymmetric information goes down with venture age as more information becomes naturally publicly available. Therefore, in line with the attention allocation theory, we expect investors' preference for local ventures, for which they have information advantages, to be particularly strong in the case of younger ventures. This yields our first hypothesis, which to the best of our knowledge has not yet been investigated empirically.

Hypothesis 1 Local preferences are more pronounced in campaigns of younger ventures.

Note that this hypothesis is not trivial. It is conceivable that older ventures have had more time to establish themselves in the local community. Consequently, local preferences might turn out to be larger in older ventures.

An important source of information in equity-based crowdfunding is the publicly observable investments of other investors. This learning mechanism can be referred to as observational learning (Bandura 1977). In financial markets, observational learning is a well-documented phenomenon (e.g., Bikhchandani et al. 1992; Bikhchandani and Sharma 2001; Devenow and Welch 1996; Zhang and Liu 2012). It may give rise to herding-like behaviour, meaning "everyone doing what everyone else is doing" (Banerjee 1992, p. 798). Recent research shows that herding-like behaviour is present on crowdfunding platforms (Burtch 2011; Lee and Lee 2012; Zhang and Liu 2012; Burtch et al. 2013; van de Rijt et al. 2014; Colombo et al. 2015; Kim et al. 2015; Moritz et al. 2015; Vulkan et al. 2016; Hornuf and Neuenkirch 2017; Vismara 2018; Åstebro et al. 2019; Zaggl and Block 2019; Walther and Bade 2020). However, no attention has been paid to the relation between rational herding-like behaviour and local preferences.

The theory on limited information processing capacity and attention allocation suggests that investors spend more attention to ventures for which they already have superior information. This implies that investors focus on local ventures when learning from previous investments of others. This yields Hypothesis 2.

\section{Hypothesis 2 Herding-like behaviour is more pronounced among local investors.}

Not only investors can reduce information asymmetries by observational learning, but signals can be used to reduce information asymmetries between agents as 
well (Spence 2002; Ahlers et al.2015). In the crowdfunding context, besides the campaign description and videos, there are updates as a means of communication and signalling. Xu et al. (2014) find that updates may have an even stronger relation to campaign success than the campaign description. In general, updates appear to have a positive effect on campaign success. Kuppuswamy and Bayus (2013) show that campaigns which have posted an update in the final stage of the campaign are more likely to succeed. Mollick (2014) provides evidence on the importance of frequent updates. In particular, he finds that campaigns without early updates are more likely to fail. By demonstrating a positive relationship between project support and updates, Kuppuswamy and Bayus (2017) provide an explanation for the importance of frequent updates. Relatedly, Hornuf and Schwienbacher (2018) show that the number of investments on a particular day increases after an update has been posted. Most recently, Block et al. (2018) identify positive effects of recent updates on the number of investments. The statistical significance of this effect decreases in the number of updates. Since updates should reduce information asymmetries, the information asymmetry between locals and non-locals might decrease as more updates are available. As a result, the local preference should decrease. This yields the following hypothesis.

\section{Hypothesis 3 Local preferences decrease with the number of updates.}

The attention investors pay to a campaign decreases over time, which is reflected by the L-shaped investment pattern (Hornuf and Schwienbacher 2018) and the "collective attention effect" introduced by Kuppuswamy and Bayus (2017). Therefore, it is to be expected that the effect of a recent update on investment probability decreases in the number of updates. Note that the number of updates may also be a proxy for the timing of an update: the higher the number of an update in the chronological order, the later the time in the campaign. However, given that investors allocate more attention to local ventures, we expect that local investors are more responsive to updates. This draws two thoughts. First, the effect of an update on investment should be stronger for local investors. Second, the decrease in the strength of each update's effect on investment should be less pronounced for locals. Therefore, we hypothesize the following.

Hypothesis 4 The effect of an update on investment probability is stronger for local investors than for non-local investors.

Hypothesis 5a The effect of an update on investment probability diminishes in the number of updates.

Hypothesis 5b The effect of an update on investment probability diminishes less quickly for local investors compared to non-local investors.

Note that Hypothesis $5 \mathrm{~b}$ is to be captured by a three-way interaction. A possible interpretation of this is that two moderators (first, the number of updates posted 
before; second, being a local) jointly affect the relationship between investment probability and a recent update. ${ }^{2}$ Put differently, we examine how the number of updates and the appearance of a recent update jointly moderate an investor's local preference.

\section{Empirical setting and data}

The platform considered in this study is called "Companisto". It has been founded in June 2012 in Berlin, Germany. Investors can contribute to a campaign by an amount of their choice. Investors receive a share in the venture's profits, which is typical for equity-based crowdfunding. In addition, investors participate in the proceeds if the start-up is sold. Each financing round runs until the maximum has been reached. The campaign duration is limited to a maximum of twelve months. In the first funding stage (target stage), a campaign has two months to reach the financing threshold $(100,000$ EUR). If a start-up does not reach the threshold in full within two months, investors get a full refund. If this stage is successfully completed, the campaign shifts to the second stage (limit stage), in which the campaign continues until reaching the funding goal. If it does not reach the financing threshold, the campaign is abandoned.

For our study, we collected data by hand of all investments that have ever been made on the platform until January 2019. Seven campaigns were not equity-based but liability-based. Furthermore, important data, such as the date of foundation of the venture, was missing for one campaign. We therefore removed eight campaigns from the data set. The reduced data set contains 63,691 investments in 93 campaigns.

All variables used in our model are depicted in italics. The campaign-related information visible to all investors on Companisto includes the campaign's name, location of the venture, goal type of the campaign (i. e. target vs. limit, Goal type), the amount requested (Goal amount), the amount of Co-financing, the Equity stake offered to investors, the current overall amount invested as well as the reached percentage of the funding goal, the status of the campaign, the number of updates (\# updates) and the date of each update. In addition to this information, we take the date of foundation of the ventures from the website of the "Bundesanzeiger" and determine the industry (SIC classification) of each venture. The 93 campaigns comprise five different industries: Manufacturing (SIC-code: D), Wholesale trade (F), Retail trade (G), Finance, insurance and real estate $(\mathrm{H})$ and Services (I).

On the investor basis, we collected data on an investor's ID, location, amount of investment and date of investment. In the next step, we pair ventures with investors on a monthly basis following the approach of Agrawal et al. (2015) and Lin and Viswanathan (2016). Therefore, we construct two lists for each month in the sample. One list contains all of the 16,559 unique investors who invested at least once by the

\footnotetext{
${ }^{2}$ In other words, this hypothesis focuses on the moderating impact of being a local investor on the moderating impact of the number of updates on the impact of an update on investment probability.
} 
month considered, implying an average number of investments of 3.85 per investor. The other list consists of the campaigns available on the platform in the month under consideration. If an investor invested in a campaign, investor and campaign are paired, which means the outcome variable (Investment) is set to 1 . Otherwise, it is set to 0 . This procedure leads to a data set of 4,875,752 campaign-investor-month observations. Note that, given the high number of potential pairs, a day-based or week-based analysis is computationally intractable.

After that, for each pair of locations in the data set, we determine latitude and longitude. With this data, we calculate the distance using the reference ellipsoid specified in the World Geodetic System 1984 (e.g., Kumar 1988). Similar to Agrawal et al. (2015), we create a dummy variable indicating whether the focal investor is a local (investor who is located less than $100 \mathrm{~km}$ from the venture, Local) or distant/non-local investor. In our sample, about $14 \%$ of all investments are local investments.

In addition, we calculate variables related to the timing of the investment, such as the number of previous investments in the campaign considered (\# previous investments), the number of investments in the two days before (\# investments two days before) and a dummy for early investments (during the first three days of the campaign, Early). We further calculate the number of potential investors for each month (\# potential investors) to control for the steadily increasing number of potential investors and the number of months a campaign has been available (Project month count). Note that these variables are all based on public information, which every investor can see. A summary of variable definitions is given in Table 2. Table 3 provides summary statistics. Table 4 contains the correlation matrix.

The mean age of ventures starting a campaign is 3.36 years. The negative minimum value for the variable Age belongs to the campaign "Freygeist". The corresponding venture was founded during the campaign, according to the "Bundesanzeiger". The maximum age is $\mathbf{1 7 . 1 9}$ years. For each investment, there have been 35.35 investments during the previous two days on average. On average, 11 percent (46 percent) of investments are made one day (within seven days) after an update has been posted. 18 percent of the 63,691 investments are classified as friends-andfamily investments.

\section{Econometric model}

Similar to Agrawal et al. (2015), we use a linear probability model but with fixed effects on both the investor level and the campaign level. The fixed effects are included in order to control for unobservable variables, such as taste, wealth, investment preferences, willingness to participate or willingness to pay (investor level) and campaign-specific factors, such as industry, venture age, goal type or amount requested, etc.

In order to test whether geographical proximity matters for investments, the variable Local is included in the model. To address Hypotheses 1 and 2, we insert interaction terms between Local and Age and between Local and \# investments two days before, respectively. The interactions between Local and \# updates and between 
Table 2 List of variables

\begin{tabular}{|c|c|}
\hline Variable name & Description \\
\hline Investment & Equals 1 if an investor invests in a campaign; 0 otherwise \\
\hline Local & $\begin{array}{l}\text { Equals } 1 \text { if investor location is not more than } 50 \mathrm{~km} \text { away from the } \\
\text { venture; } 0 \text { otherwise }\end{array}$ \\
\hline Age & Age of the venture at the start of the campaign in years \\
\hline \# investments two days before & $\begin{array}{l}\text { Number of investments made in the two days before the investment } \\
\text { considered }\end{array}$ \\
\hline Update previous day & Equals 1 if there has been an update the day before \\
\hline Update previous week & Equals 1 if there has been an update within seven days before \\
\hline \# updates & Number of updates posted before the investment considered \\
\hline Manufacturing & Equals 1 if the SIC-code for the venture's industry is D (manufacturing) \\
\hline Wholesale trade & Equals 1 if the SIC-code for the venture's industry is F (wholesale trade) \\
\hline Retail trade & Equals 1 if the SIC-code for the venture's industry is G (retail trade) \\
\hline Finance & $\begin{array}{l}\text { Equals } 1 \text { if the SIC-code for the venture's industry is } \mathrm{H} \text { (finance, insur- } \\
\text { ance and real estate) }\end{array}$ \\
\hline Services & Equals 1 if the SIC-code for the venture's industry is I (services) \\
\hline Early & $\begin{array}{l}\text { Equals } 1 \text { if investment decision is during the first three days of the cam- } \\
\text { paign; } 0 \text { otherwise }\end{array}$ \\
\hline \# previous investments & Number of all investments in the venture made before \\
\hline \# potential investors & $\begin{array}{l}\text { Number of active investors (those who have invested before) on the } \\
\text { platform }\end{array}$ \\
\hline Project month count & $\begin{array}{l}\text { The number of months a campaign has been available on the platform by } \\
\text { the considered month }\end{array}$ \\
\hline Campaign Berlin & Equals 1 if the venture's location is Berlin \\
\hline Goal type & $\begin{array}{l}\text { Equals } 1 \text { if the campaign's goal type is "target"; } 0 \text { if the goal type is } \\
\text { "limit" }\end{array}$ \\
\hline Goal amount & Requested amount of capital by the venture (in EUR million) \\
\hline Co-financing & $\begin{array}{l}\text { Equals } 1 \text { if the campaign has been co-financed by an institutional inves- } \\
\text { tor; } 0 \text { otherwise }\end{array}$ \\
\hline Equity stake offered & Percentage of Equity offered \\
\hline Friends \& family & $\begin{array}{l}\text { Equals } 1 \text { if an investor is a friend or family member using the method } \\
\text { described in Agrawal et al. (2015); } 0 \text { otherwise }\end{array}$ \\
\hline
\end{tabular}

Note: This table provides an overview of variables used in the regressions

Local and Update previous day address Hypothesis 3 and Hypothesis 4, respectively. The interactions between Update previous day and \# updates as well as between Local, Update previous day and \# updates are considered to test Hypothesis 5a and Hypothesis $5 b$.

Since the influence of being a local on investments might differ across industries, we insert interaction terms between Local and industry dummies into the model. To address the particularities of early-stage investments, the dummy variable Early, that indicates whether an investment was made in the first three days of a campaign and the interaction between Early and Local are included in the regression. Note that this variable is also important to ensure that the results with respect to the impact of previous investments are not driven by high numbers of investments during the first 
Table 3 Summary statistics

\begin{tabular}{|c|c|c|c|c|c|}
\hline Variable & $\mathrm{N}$ & Mean & SD & Min & $\operatorname{Max}$ \\
\hline Local & 63,691 & 0.14 & 0.34 & 0 & 1 \\
\hline Age & 63,691 & 3.36 & 3.95 & -0.09 & 17.19 \\
\hline \# investments two days before & 63,691 & 35.35 & 62.53 & 0 & 562 \\
\hline Update previous day & 63,691 & 0.11 & 0.31 & 0 & 1 \\
\hline Update previous week & 63,691 & 0.46 & 0.50 & 0 & 1 \\
\hline \# updates & 63,691 & 3.68 & 4.12 & 0 & 26 \\
\hline Manufacturing & 63,691 & 0.30 & 0.46 & 0 & 1 \\
\hline Wholesale trade & 63,691 & 0.01 & 0.10 & 0 & 1 \\
\hline Retail trade & 63,691 & 0.15 & 0.36 & 0 & 1 \\
\hline Finance & 63,691 & 0.02 & 0.12 & 0 & 1 \\
\hline Services & 63,691 & 0.52 & 0.50 & 0 & 1 \\
\hline Early & 63,691 & 0.21 & 0.41 & 0 & 1 \\
\hline \# previous investments & 63,691 & 442.64 & 394.76 & 0 & 2,273 \\
\hline \# potential investors & 63,691 & 8,901 & 4,597 & 39 & 16,414 \\
\hline Project month count & 63,691 & 2.34 & 2.83 & 1 & 13 \\
\hline Campaign Berlin & 63,691 & 0.48 & 0.50 & 0 & 1 \\
\hline Goal type & 63,691 & 0.68 & 0.47 & 0 & 1 \\
\hline Goal amount & 63,691 & 0.83 & 0.89 & 0.05 & 5.5 \\
\hline Co-financing & 63,691 & 0.07 & 0.26 & 0 & 1 \\
\hline Equity stake offered & 63,691 & 13.01 & 7.98 & 2.44 & 37.50 \\
\hline Friends \& family & 63,691 & 0.18 & 0.38 & 0 & 1 \\
\hline Local & 52,530 & 0.14 & 0.34 & 0 & 1 \\
\hline Age & 52,530 & 3.41 & 3.99 & -0.09 & 17.19 \\
\hline \# investments two days before & 52,530 & 35.46 & 62.33 & 0 & 562 \\
\hline Update previous day & 52,530 & 0.11 & 0.31 & 0 & 1 \\
\hline Update previous week & 52,530 & 0.46 & 0.50 & 0 & 1 \\
\hline \# updates & 52,530 & 3.53 & 4.05 & 0 & 26 \\
\hline Manufacturing & 52,530 & 0.30 & 0.46 & 0 & 1 \\
\hline Wholesale trade & 52,530 & 0.01 & 0.10 & 0 & 1 \\
\hline Retail trade & 52,530 & 0.15 & 0.36 & 0 & 1 \\
\hline Finance & 52,530 & 0.02 & 0.12 & 0 & 1 \\
\hline Services & 52,530 & 0.52 & 0.50 & 0 & 1 \\
\hline Early & 52,530 & 0.39 & 0.49 & 0 & 1 \\
\hline \# previous investments & 52,530 & 420.2 & 382.04 & 0 & 2,273 \\
\hline \# potential investors & 52,530 & 9,005 & 4,575 & 39 & 16,414 \\
\hline Project month count & 52,530 & 2.28 & 2.84 & 1 & 13 \\
\hline Campaign Berlin & 52,530 & 0.47 & 0.50 & 0 & 1 \\
\hline Goal type & 52,530 & 0.68 & 0.47 & 0 & 1 \\
\hline Goal amount & 52,530 & 0.82 & 0.88 & 0.05 & 5.5 \\
\hline Co-financing & 52,530 & 0.07 & 0.26 & 0 & 1 \\
\hline Equity stake offered & 52,530 & 12.89 & 7.89 & 2.44 & 37.50 \\
\hline
\end{tabular}

Notes: This table provides summary statistics for our data set. The upper part of the table includes friends-and-family investments while the lower part of the table excludes friends-and-family-investments. The negative minimum value for the variable Age belongs to the campaign "Freygeist". The corresponding venture was founded during the campaign, according to the "Bundesanzeiger" 
days. We control for the total number of previous investments (\# previous investments) in the campaign, the number of investments in the two days before (\# investments two days before) and whether there has been an update the day before the investment considered (Update previous day).

Thus, the main model's regression formula is specified as follows:

$$
\begin{array}{r}
\text { Investment }=\beta_{1} \cdot \text { Local } \\
+\beta_{2} \cdot[\text { Update previous day } \cdot \# \text { updates }] \\
+\beta_{3} \cdot[\text { Local } \cdot \text { Age }] \\
+\beta_{4} \cdot[\text { Local } \cdot \text { \# investments two days before }] \\
+\beta_{5} \cdot[\text { Local } \cdot \# \text { updates }] \\
+\beta_{7} \cdot[\text { Local } \cdot \text { Update previous day } \cdot \# \text { updates }] \\
+ \text { Controls } \\
+ \text { Investor fixed effects } \\
+ \text { Campaign fixed effects } \\
+ \text { Error terms }
\end{array}
$$

In our main model, we exclude friends-and-family investments. Note that we adopt the criteria of Agrawal et al. (2015) for friends and family of a venture: (1) they invest in the focal start-up before investing in any other start-up, (2) that investment is the largest of their investments on the website and (3) they invest in no more than three other campaigns. The fact that friends and family behave differently has been shown by previous research. Their investment decisions may depend less on measurable factors, such as proximity. Instead, they guide their investments by personal ties, which may overcome geographical distances. Given that friends and family are typically closer to the venture, their investments drive local bias (Agrawal et al. 2015). In our sample, 18 percent of investments are identified as friends-and-family investments. This seems to be a relatively high percentage, which suggests that the criteria of Agrawal et al. (2015) might not be strict enough for our data set, meaning that too many investors are identified as friends and family. Consequently, the number of excluded investors is likely to be higher than the actual number of friends-and-family investors. To check the robustness of our results, we include the investors identified as friends and family in an additional regression. Since the qualitative results remain unchanged, it is likely that these investors do not explain the effects found in our study to a large extent.

In our robustness checks, we consider an alternative definition of the Local variable (50 km). In Germany, distances are much smaller than in the USA, which is the country Agrawal et al. (2015) examine. Therefore, we argue that only a stricter definition of being a local needs to be considered. Next, we consider updates within seven days before the investment (Update previous week). Furthermore, we vary the number of days used in our variables that capture herding-like behaviour, i. e. we use \# investments one day before and \# investments three days before. As explained above, in a further test, we include friends-and-family investors. In addition, we remove the campaign fixed effects 


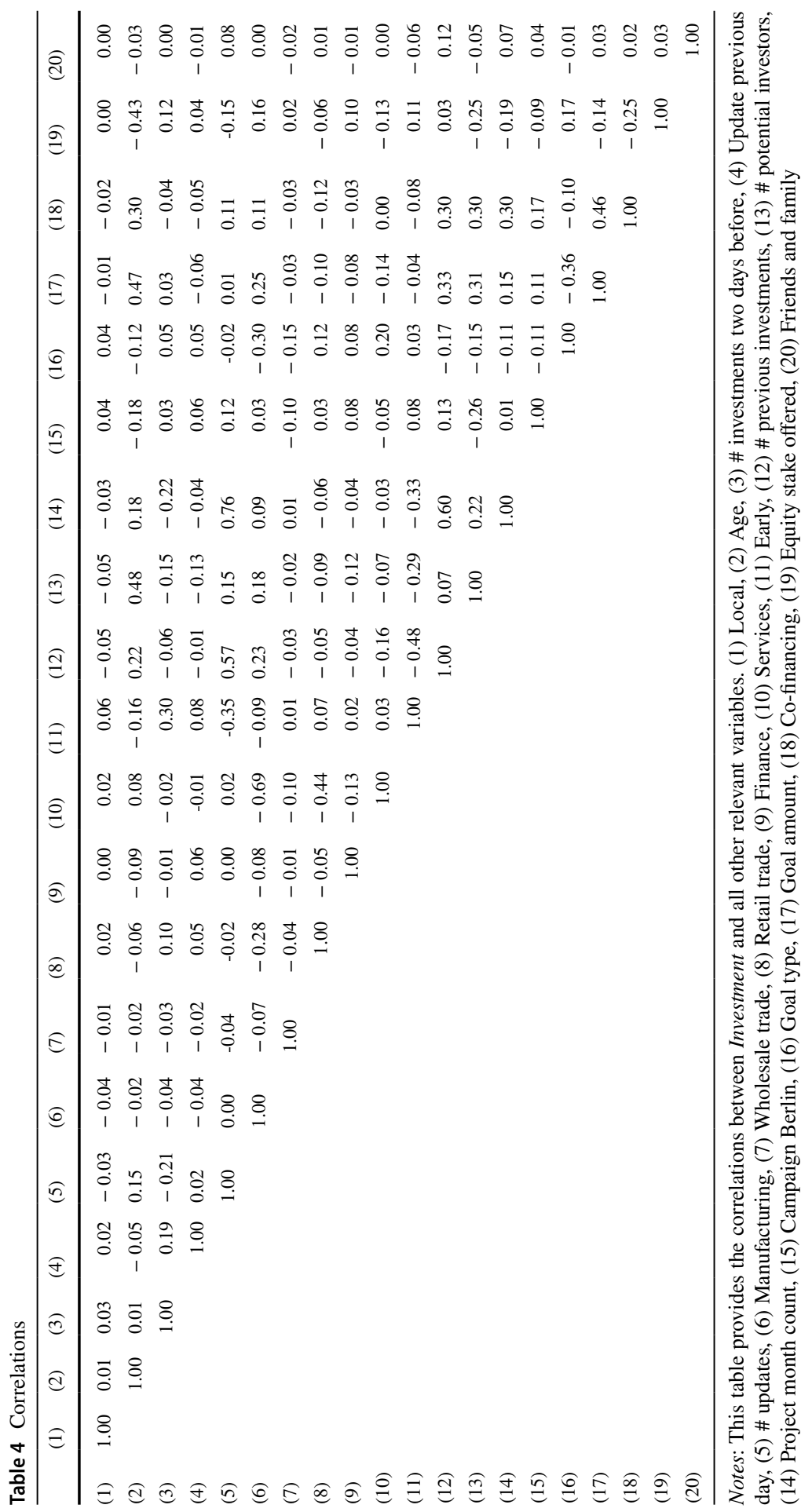


Table 5 Main model

Dependent variable:

Investment

(1)

(2)

\begin{tabular}{|c|c|c|}
\hline Local & $0.0056^{* * *}(0.0008)$ & $0.0133 * * *(0.0009)$ \\
\hline \# previous investments & $0.0001 * * *(0.000001)$ & $0.0001 * * *(0.000001)$ \\
\hline \# investments two days before & $0.0006 * * *(0.00001)$ & $0.0007 * * *(0.00001)$ \\
\hline Project month count & $0.0058 * * *(0.0001)$ & $0.0066 * * *(0.0001)$ \\
\hline Early & $0.1326 * * *(0.0008)$ & $0.1527 * * *(0.0009)$ \\
\hline \# updates & $-0.0017 * * *(0.00005)$ & $-0.0021 * * *(0.0001)$ \\
\hline Update previous day & $0.0088 * * *(0.0006)$ & $0.0095 * * *(0.0007)$ \\
\hline \# updates $*$ Update previous day & $-0.0012 * * *(0.0001)$ & $-0.0015^{* * *}(0.0001)$ \\
\hline Local * Age & $-0.0002 * * *(0.0001)$ & $-0.0007 * * *(0.0001)$ \\
\hline Local $* \#$ investments two days before & $0.0002 * * *(0.00002)$ & $0.0001 * * *(0.00002)$ \\
\hline Local * \# updates & $0.0001(0.0001)$ & $0.00004(0.0001)$ \\
\hline Local $*$ Update previous day & $0.0010(0.0018)$ & $-0.0033 *(0.0020)$ \\
\hline Local * \# updates * Update previous day & $0.0004 * *(0.0002)$ & $0.0014 * * *(0.0002)$ \\
\hline Local * Early & $-0.0053^{* * *}(0.0014)$ & $-0.0008(0.0016)$ \\
\hline Local * Manufacturing & $-0.0007(0.0008)$ & $-0.0020 * *(0.0009)$ \\
\hline Local $*$ Wholesale trade & $-0.0070 * *(0.0034)$ & $-0.0100 * * *(0.0038)$ \\
\hline Local $*$ Finance & $-0.0185 * * *(0.0021)$ & $-0.0276 * * *(0.0023)$ \\
\hline Local $*$ Services & $0.0018 * *(0.0008)$ & $0.0007(0.0008)$ \\
\hline Observations & $4,838,429$ & $4,875,752$ \\
\hline $\mathrm{R}^{2}$ & 0.2386 & 0.2189 \\
\hline Adjusted $\mathrm{R}^{2}$ & 0.2360 & 0.2163 \\
\hline Residual Std. Error & $0.1690(\mathrm{df}=4,821,834)$ & $0.1859(\mathrm{df}=4,859,083)$ \\
\hline
\end{tabular}

Dependent variable: Investment. Regression type: Linear probability model with investor fixed effects and campaign fixed effects. Standard errors in parentheses. ${ }^{*} p<0.1 ; * * p<0.05$; $* * * p<0.01$. Model 1 : Main model excluding Friends and family. Model 2: Main model including Friends and family

and include campaign-level variables, such as \# potential investors, Age, industry types, Goal type, Goal amount, Co-financing, Campaign Berlin and Equity stake offered.

\section{Results}

In this section, we present our results. Table 5 depicts our main model's regression coefficients with standard errors.

The regression results of our main model (model 1) show that investors tend to invest in local campaigns. The effect is statistically significant. The coefficient of Local amounts to $0.6 \%$ points. Note that in our final data set, the proportion of Investment values of 1 is about 4 percent. To get a rough idea on economic significances, we consider the partial effects on an average investor. The effect appears to be economically significant, as it corresponds to an increase in investment 
probability of about $16 \%{ }^{3}$ Our result is consistent with previous findings on the existence of local preferences in crowdfunding (e.g., Agrawal et al. 2015; Lin and Viswanathan 2016; Guenther et al. 2018; Hornuf et al. 2020).

We can confirm Hypothesis 1, as we find a significantly negative coefficient of the interaction between Local and Age. The effect strength amounts to 0.02 percentage points. Given the standard deviation of Age of 3.99 years, this means that an increase of Age equal to one standard deviation decreases the investment probability of a local investor by about 2 percent, which may be economically significant.

Regarding herding-like behaviour, we find positive effects of the total number of previous investments (\# previous investments), the number of recent previous investments (\# investments two days before) and a positive coefficient of the interaction between Local and \# investments two days before. The former two results are in line with recent findings in the literature on herding in equity-based crowdfunding (e.g., Hornuf and Neuenkirch 2017; Åstebro et al. 2019; Walther and Bade 2020). The results on the interaction term confirm Hypothesis 2. All effects are statistically significant. The standard deviation of \# investments two days before is 62.33 , which implies an increase of investment probability by about 31 percent when the number of investments during the two days before increases by one standard deviation. The effect is therefore likely to be economically significant.

Next, we turn to the impact of updates on investment probability. In line with recent research, we find a positive effect of a recent update. The coefficient is 0.009 and significant. This means that an update can increase the investment probability of a non-local by up to 23 percent. In addition, we find that the investment probability is negatively related to the number of updates.

We cannot confirm Hypothesis 3 because the coefficient of the interaction between Local and \# updates is positive and statistically insignificant. This means that local preferences do not diminish with the number of updates posted. Our results do not confirm Hypothesis 4, as the coefficient of the interaction between Local and Update previous day is not significant. However, we can confirm Hypothesis 5a. The coefficient of the interaction between Update previous day and \# updates is significantly negative. It amounts to -0.12 percentage points. This corresponds to a reduction of the positive effect of an update of up to 23 percent on investment probability by $14 \%$. This indicates the economic significance of this effect, which to the best of our knowledge is new to the literature. The three-way interaction between Local, \# updates and Update previous day yields a significant coefficient of 0.04 percent points. Therefore, the decrease of the effect of an update with each update is 30 percent $(=0.0004 / 0.0012)$ less for locals compared to non-locals. Note that excluding the interactions relevant for Hypothesis 5a and Hypothesis $5 \mathrm{~b}$ leads to a significantly positive coefficient of Local * Update previous day (see model 11 in Table 9). This implies that locals are in general more responsive to updates.

\footnotetext{
${ }^{3}$ Note that, due to the structure of our data set, the effect sizes are small. This is mainly because we have few investments, but many non-investments. When excluding investor and campaign fixed effects, Cohen's $f^{2}$ (see Cohen 1988) amounts to 0.013. The variable Early (including its interaction with Local) has the largest contribution (about half) to this. The rest of $f^{2}$ is divided among the other variables. For example, the herding-related variables account for a $f^{2}$ of about 0.002 .
} 
In addition to our main results, we find that local preferences are different across industries. In particular, our results indicate that local preferences are less pronounced in campaigns of ventures in the finance industry and wholesale trade, when compared to retail trade. In contrast, local preferences appear to be stronger in the services industry. This might be due to the fact that finance and wholesale trade are less regionally bound, which might result in smaller information advantages of locals. On the contrary, services are more often regionally bound and have to be used locally. Hence, local investors may have an easier time to gain information advantages over distant investors. Another interpretation relates to Belleflamme et al. (2014). In their model, community benefits drive crowdfunding investments. As such benefits may result from consuming a product or service, locals are more likely to benefit from the additional utility when the venture provides, for example, locally bound services instead of non-local financial products. In this sense, our results are consistent with the theory developed by Belleflamme et al. (2014). Note that only a few campaigns are from the finance and wholesale trade industries.

In line with previous research, we can confirm the existence of an L-shaped pattern among investments (Hornuf and Schwienbacher 2018), as the coefficient of Early is 0.133 . Compared to the overall proportion of Investment values of 1 of about 4 percent, this effect appears to be of high economic significance. In the main model, the effect of the interaction between Local and Early is negative. However, the sign of this effect differs among regressions. This is why we do not further discuss this effect.

Our main qualitative findings are robust to various alternative specifications. The regression results are provided in Table 5 (model 2) and in the tables in the Appendix. Regarding the different effect of updates on locals, there are small differences between the regression results, which do not change the qualitative conclusion. In particular, a stricter definition of locals $(50 \mathrm{~km}$, Table 7) yields an additional positive and significant coefficient of the interaction between Local and Update previous day. This provides support for Hypothesis 4. Looking at the regression that includes friends-and-family investors (model 2 in Table 5), there is a negative coefficient $(-0.003)$ of the interaction between Local and Update previous day. However, as in the main model, the coefficient of the interaction between Local, Update previous day and \# updates is positive (0.0014). The average number of updates is 3.53 , meaning that the average effect of an update is still stronger for local investors. The fact that the difference between locals and non-locals is weaker in terms of responsiveness to updates is not surprising. Agrawal et al. (2015) have shown that friendsand-family investors behave differently. These investors are likely to invest in the early stages, regardless of being a local or whether there have been any updates. This, in fact, may dilute our results, especially regarding updates in the early stages, in this regression. Substituting campaign fixed effects (Table 8) by campaign control variables does not change any of our main results. Regarding the robustness test using Update previous week instead of Update previous day (Table 6), the significantly negative coefficient of Local * Update previous week is surprising. This may indicate that non-locals take more time to respond to a recent update because they follow the campaign with less attention and thus notice the update later. Note that the result concerning the three-way interaction remains unchanged. 


\section{Discussion}

Our analysis shows that local preferences exist in equity-based crowdfunding. Local preferences are stronger, the younger the ventures. We argue that information asymmetries may be larger in young ventures. Therefore, our result is in line with the theory that information advantages drive local preferences. Furthermore, our finding that updates have a stronger and more persistent positive effect on investment probability in local campaigns suggests that investors allocate more attention to local ventures and are thus more responsive to signals on these ventures. This is also expressed by the fact that investors are more responsive to recent investments in local campaigns and thus show stronger herding-like behaviour than in non-local campaigns. Therefore, our results are consistent with the theory that investors need to allocate their scarce attention resources to selected campaigns, which, in turn, drives local preferences. Thus, our results provide general support for the attentionallocation-based theory as an explanation for local preferences introduced by van Nieuwerburgh and Veldkamp (2009) and Mondria and Wu (2010).

\subsection{Implications}

Our findings have implications for entrepreneurs, investors and platforms. In addition, our results can be used to develop new hypotheses that can provide the basis for future research. First, our results enable investors to better learn from the investments of others by providing a deeper understanding behind the drivers of investment probability.

Second, we find that local preferences cannot fully be explained by friends and family. This is in contrast to Agrawal et al. (2015) but supports the more recent finding of Hornuf et al. (2020). In order to make use of local preferences, entrepreneurs may want to locate their headquarters in densely populated regions. This is especially relevant for campaigns with potentially high information asymmetries, such as young ventures, since local preferences are particularly pronounced in campaigns of these ventures.

Third, our results suggest that locals are likely to be over-represented not only in the group of actual investors, but also in the group of potential investors who regularly follow the campaign and its updates. Entrepreneurs should keep this in mind when creating the campaign description as well as the content and formulation of updates. For example, regional aspects could be emphasized.

Fourth, we provide evidence on herding-like behaviour, which is particularly pronounced among local investors. Accordingly, when calculating the marketing budget, entrepreneurs should consider multiplier effects resulting from herding behaviour. They should also be aware that marketing targeted to locals is especially fruitful because their probability of investment is higher. The existence of herding-like behaviour implies that investors learn from previous investments. Platforms could support this learning by publicly showing all previous investments in detailed form (including date, amount, location of investor, etc.) and also offering cumulative information, such as the number of investments or the amount 
collected to date, in an easily understandable form. Whether this is desirable from the perspective of the ventures is an interesting research question. This could be approached as follows: Learning from previous investments should reduce information asymmetry and thereby increase the willingness to invest and ultimately the probability of campaign success. This hypothesis could be checked by comparing the campaign success on platforms that display previous investments in different levels of detail. Empirically, such an investigation should be possible, since platforms proceed very differently regarding the display of previous investments. For example, the oldest German crowdfunding platform "Seedmatch" does not provide information on individual investments, but only cumulative information. In contrast, all previous individual investments can be tracked on Companisto.

Fifth, we find that locals are more responsive to signals, such as updates or previous investments. This supports the hypothesis that information asymmetries in connection with attention allocation explain a substantial part of local preferences and that these are not only caused by social ties, such as friends and family. To further unravel whether information asymmetries or investor attention allocation is crucial, it would be interesting for future research to take a closer look at the relationship between updates and investment probability. Our results suggest that locals react more strongly (than non-locals) to later updates. Since we are only looking at the number of updates, we cannot conclusively determine whether the lower information asymmetry due to the updates or the lower investor attention due to the late point in time is the decisive factor. By additionally considering the exact timing of an update (relative to the start of the campaign), future studies could clarify this. Furthermore, it would be interesting to consider the "size" of an update. It is conceivable that nonlocal investors do not notice all small updates but pay attention to major updates. Accordingly, future studies could test the hypothesis that locals react comparatively stronger to minor updates, while non-locals react stronger to major updates.

\subsection{Limitations}

In our analysis, we do not distinguish between different types of updates, such as minor vs. major updates and ease of language (see, e.g., Block et al., 2018). Moreover, Companisto does not provide information on investor type (e.g. sophisticated vs. unsophisticated), wealth, risk tolerance and social connections. Therefore, we have to include investor-level fixed effects, which do not perfectly control for investor characteristics. To account for friends and family, we use the approach of Agrawal et al. (2015), which is only an approximation. Hence, we cannot fully rule out that these investors may explain local preferences to a larger extent. For example, the percentage of friend-and-family investors might be higher for younger ventures, which would also result in local preferences being more pronounced. However, the founders of older ventures are likely to have larger personal networks than young entrepreneurs. It is therefore ambiguous whether friends and family should account for a larger share of investors in campaigns of younger or older ventures. We are confident that our results are not only driven by the fact that we cannot perfectly control for investor characteristics. 
We also cannot rule out that our results are driven by behavioural explanations or biases, as we can only observe investments but not the motivation of investors. Since our results are consistent with the predictions based on the attention allocation theory, it is likely that economic reasons are at least partially responsible for the observed effects.

\section{Concluding remarks}

This study investigated drivers of investment probability in equity-based crowdfunding. Novel to the crowdfunding literature, we examined interactions between local preferences of investors and drivers of investment probability in the light of asymmetric information and investors' allocation of attention. Our results provide support for the rationale that investors prefer to allocate their attention to local campaigns for which they have information advantages and that this may be explained by their limited capacity to process information. Our findings do not seem to be largely driven by social explanations (friends and family).

The main contribution of our study is the following. We show that the explanation of home bias developed by van Nieuwerburgh and Veldkamp (2009) and Mondria and Wu (2010) on country-level international investment behaviour might apply to equity-based crowdfunding and thus to unsophisticated small investors. Previous research suggests that less informed investors are more responsive to signals than well informed ones. For example, Agrawal et al. (2015) find that distant investors are more responsive to information on cumulative investment than locals. In contrast, our study shows that presumably well-informed locals are more responsive to signals, such as previous investments and updates, compared to non-locals. In a way, this suggests that equity-based crowdfunding is different in the sense that economic theories which posit signalling as a mechanism to alleviate asymmetric information (e.g., Spence 1973) are not applicable to crowdfunding beyond reasonable doubt. Consistent with van Nieuwerburgh and Veldkamp (2009), our findings suggest that information signals may amplify information asymmetry and local preferences of investors in equity-based crowdfunding.

\section{Appendix}

See Tables 6, 7, 8 and 9 . 
Table 6 Robustness tests (1/3)

Dependent variable:

$$
\text { Investment }
$$

(3)

Local
\# previous investments
\# investments two days before
\# investments one day before
\# investments three days before

Project month count

Early

\# updates

Update previous week

\# updates * Update previous week

Update previous day

\# updates * Update previous day

Local * Age

Local * \# investments two days before

Local * \# investments one day before

Local * \# investments three days before

Local * \# updates

Local * Update previous week

Local * \# updates * Update previous week

Local * Update previous day

Local * \# updates * Update previous day

Local * Early

$-$

$-$

$0.006 * * *$

(0.001)

$0.00005 * * *$

(0.000001)

$0.001 * * *$

(0.00001)

$0.006 * * *$
$(0.0001)$
$0.137 * * *$
$(0.001)$

$-0.0003 * * *$

(0.0001)

$0.012 * * *$

(0.0003)

$-0.002 * * *$

$(0.00005)$

\begin{tabular}{|c|c|c|}
\hline- & $\begin{array}{l}0.008 * * * \\
(0.001)\end{array}$ & $\begin{array}{l}0.009 * * * \\
(0.001)\end{array}$ \\
\hline- & $\begin{array}{l}-0.001 * * * \\
(0.0001)\end{array}$ & $\begin{array}{l}-0.001 * * * \\
(0.0001)\end{array}$ \\
\hline $\begin{array}{l}-0.0003 * * * \\
(0.0001)\end{array}$ & $\begin{array}{l}-0.0002 * * * \\
(0.0001)\end{array}$ & $\begin{array}{l}-0.0002^{* * * *} \\
(0.0001)\end{array}$ \\
\hline $\begin{array}{l}0.0002 * * * \\
(0.00002)\end{array}$ & - & - \\
\hline- & $\begin{array}{l}0.0002 * * * \\
(0.00003)\end{array}$ & - \\
\hline- & - & $\begin{array}{l}0.0001 * * * \\
(0.00001)\end{array}$ \\
\hline $\begin{array}{l}-0.0001 \\
(0.0001)\end{array}$ & $\begin{array}{l}0.00001 \\
(0.0001)\end{array}$ & $\begin{array}{l}0.0001 * * \\
(0.0001)\end{array}$ \\
\hline $\begin{array}{l}-0.002^{*} \\
(0.001)\end{array}$ & - & - \\
\hline $\begin{array}{l}0.0004 * * * \\
(0.0001)\end{array}$ & - & - \\
\hline- & $\begin{array}{l}-0.001 \\
(0.002)\end{array}$ & $\begin{array}{l}0.002 \\
(0.002)\end{array}$ \\
\hline- & $\begin{array}{l}0.001 * * * \\
(0.0002)\end{array}$ & $\begin{array}{l}0.0003 * \\
(0.0002)\end{array}$ \\
\hline $\begin{array}{l}-0.006^{* * * *} \\
(0.001)\end{array}$ & $\begin{array}{l}-0.006 * * * \\
(0.001)\end{array}$ & $\begin{array}{l}-0.004 * * * \\
(0.001)\end{array}$ \\
\hline
\end{tabular}

$0.004 * * *$ (0.001)

$0.0001 * * *$ (0.000001)

$(0.000001) \quad(0.000001)$$$
\text { (0.00001) }
$$$$
\text { - } \quad 0.0004 * * *
$$

(0.00001)

$0.006 * * *$

(0.0001)

$(0.0001)$

$0.139 * * *$

(0.001)

$-0.002 * * *$

(0.00005)

(0.00005)

$-$

$0.009 * * *$

0.001

$(0.0001)$

$-0.0002 * * *$

$0.0001 * * *$

(1)

$\begin{array}{ll}(0.001) & (0.001) \\ -0.002 * * * & -0.002 * * * \\ (0.00005) & (0.00005)\end{array}$

(5)

\section{.}


Table 6 (continued)

\begin{tabular}{llll}
\hline & \multicolumn{2}{l}{ Dependent variable: } & \\
\cline { 2 - 4 } & \multicolumn{2}{l}{ Investment } & \\
\cline { 2 - 4 } & $(3)$ & $(4)$ & $(5)$ \\
\hline Local * Manufacturing & -0.0003 & -0.0003 & -0.001 \\
& $(0.001)$ & $(0.001)$ & $(0.001)$ \\
Local * Wholesale trade & $-0.007 * *$ & $-0.007 * *$ & $-0.007 *$ \\
& $(0.003)$ & $(0.003)$ & $(0.003)$ \\
Local * Finance & $-0.018 * * *$ & $-0.018 * * *$ & $-0.018 * * *$ \\
Local * Services & $(0.002)$ & $(0.002)$ & $(0.002)$ \\
Observations & $0.003 * * *$ & $0.002 * *$ & $0.002 * *$ \\
$\mathrm{R}^{2}$ & $(0.001)$ & $(0.001)$ & $(0.001)$ \\
Adjusted $\mathrm{R}^{2}$ & $4,838,429$ & $4,838,429$ & $4,838,429$ \\
Residual Std. Error $(\mathrm{df}=4,821,834)$ & 0.239 & 0.240 & 0.238 \\
\hline
\end{tabular}

Dependent variable: Investment. Regression type: Linear probability model with investor fixed effects and campaign fixed effects. Standard errors in parentheses. ${ }^{*} p<0.1 ; * * p<0.05 ; * * * p<0.01$. Model 3 : Robustness test with Update previous week. Model 4: Robustness test with \# investments one day before. Model 5: Robustness test with \# investments three days before. In this table, some values have been strongly rounded due to lack of space 
Table 7 Robustness tests (2/3)

Dependent variable:

Investment

(6)

Local

\# previous investments

\# investments two days before

Project month count

Early

\# updates

Update previous day

\# updates * Update previous day

Local * Age

Local * \# investments two days before

Local * \# updates

Local * Update previous day

Local * \# updates * Update previous day

Local * Early

Local * Manufacturing

Local * Wholesale trade

Local * Finance

Local * Services

Observations

$\mathrm{R}^{2}$

Adjusted $\mathrm{R}^{2}$

Residual Std. Error
$0.0080 * * *(0.0010)$

$0.0001 * * *(0.000001)$

$0.0006^{* * *}(0.00001)$

$0.0058 * * *(0.0001)$

$0.1281 * * *(0.0008)$

$-0.0017 * * *(0.00005)$

$0.0083 * * *(0.0006)$

$-0.0012 * * *(0.0001)$

$-0.0008 * * *(0.0001)$

$0.00004 * *(0.00002)$

$0.0003 * * *(0.0001)$

$0.0069 * * *(0.0024)$

$0.0005 * *(0.0002)$

$0.0483 * * *(0.0019)$

$0.0010(0.0010)$

$-0.0174 * * *(0.0042)$

$-0.0421 * * *(0.0029)$

$0.0001(0.0009)$

$4,838,429$

0.2388

0.2362

$0.1690(\mathrm{df}=4,821,834)$

Dependent variable: Investment. Regression type: Linear probability model with investor fixed effects and campaign fixed effects. Standard errors in parentheses. $* p<0.1 ; * * p<0.05 ; * * * p<0.01$. Model 6 : Robustness test with Local $(50 \mathrm{~km})$ 
Table 8 Robustness tests (3/3)

Dependent variable:

Investment

(7)

\begin{tabular}{|c|c|}
\hline Manufacturing & $-0.0006 * *(0.0003)$ \\
\hline Wholesale trade & $-0.0044 * * *(0.0010)$ \\
\hline Finance & $0.0083 * * *(0.0007)$ \\
\hline Services & $-0.0019 * * *(0.0003)$ \\
\hline Campaign Berlin & $0.0036^{* * *}(0.0002)$ \\
\hline Goal type & $0.0080 * * *(0.0002)$ \\
\hline Goal amount & $0.0027 * * *(0.0002)$ \\
\hline Equity stake offered & $0.0001 * * *(0.00002)$ \\
\hline Co-financing & $-0.0159 * * *(0.0005)$ \\
\hline \# potential investors & $-0.00001^{* * *}(0.000000)$ \\
\hline Age & $-0.0006^{* * *}(0.00003)$ \\
\hline Local & $0.0059 * * *(0.0008)$ \\
\hline \# previous investments & $0.0001 * * *(0.000000)$ \\
\hline \# investments two days before & $0.0007 * * *(0.00001)$ \\
\hline Project month count & $0.0038 * * *(0.0001)$ \\
\hline Early & $0.0664 * * *(0.0005)$ \\
\hline \# updates & $-0.0006^{* * *}(0.00003)$ \\
\hline Update previous day & $0.0111 * * *(0.0006)$ \\
\hline \# updates $*$ Update previous day & $-0.0012 * * *(0.0001)$ \\
\hline Local * Age & $-0.0004 * * *(0.0001)$ \\
\hline Local * \# investments two days before & $0.0002 * * *(0.00002)$ \\
\hline Local * \# updates & $-0.00003(0.0001)$ \\
\hline Local * Update previous day & $0.0049 * * *(0.0018)$ \\
\hline Local * \# updates * Update previous day & $-0.0001(0.0002)$ \\
\hline Local * Early & $0.0090 * * *(0.0014)$ \\
\hline Local * Manufacturing & $0.0006(0.0008)$ \\
\hline Local * Wholesale trade & $-0.0071^{* *}(0.0034)$ \\
\hline Local $*$ Finance & $-0.0198 * * *(0.0021)$ \\
\hline Local * Services & $0.0025 * * *(0.0008)$ \\
\hline Observations & $4,838,429$ \\
\hline $\mathrm{R}^{2}$ & 0.2306 \\
\hline Adjusted $\mathrm{R}^{2}$ & 0.2280 \\
\hline Residual Std. Error & $0.1699(\mathrm{df}=4,821,915)$ \\
\hline
\end{tabular}

Dependent variable: Investment. Regression type: Linear probability model with investor fixed effects. Standard errors in parentheses. ${ }^{*} p<0.1 ; * * p<0.05$; ***p $p<0.01$. Model 7 : Robustness test with campaign variables instead of campaign fixed effects 


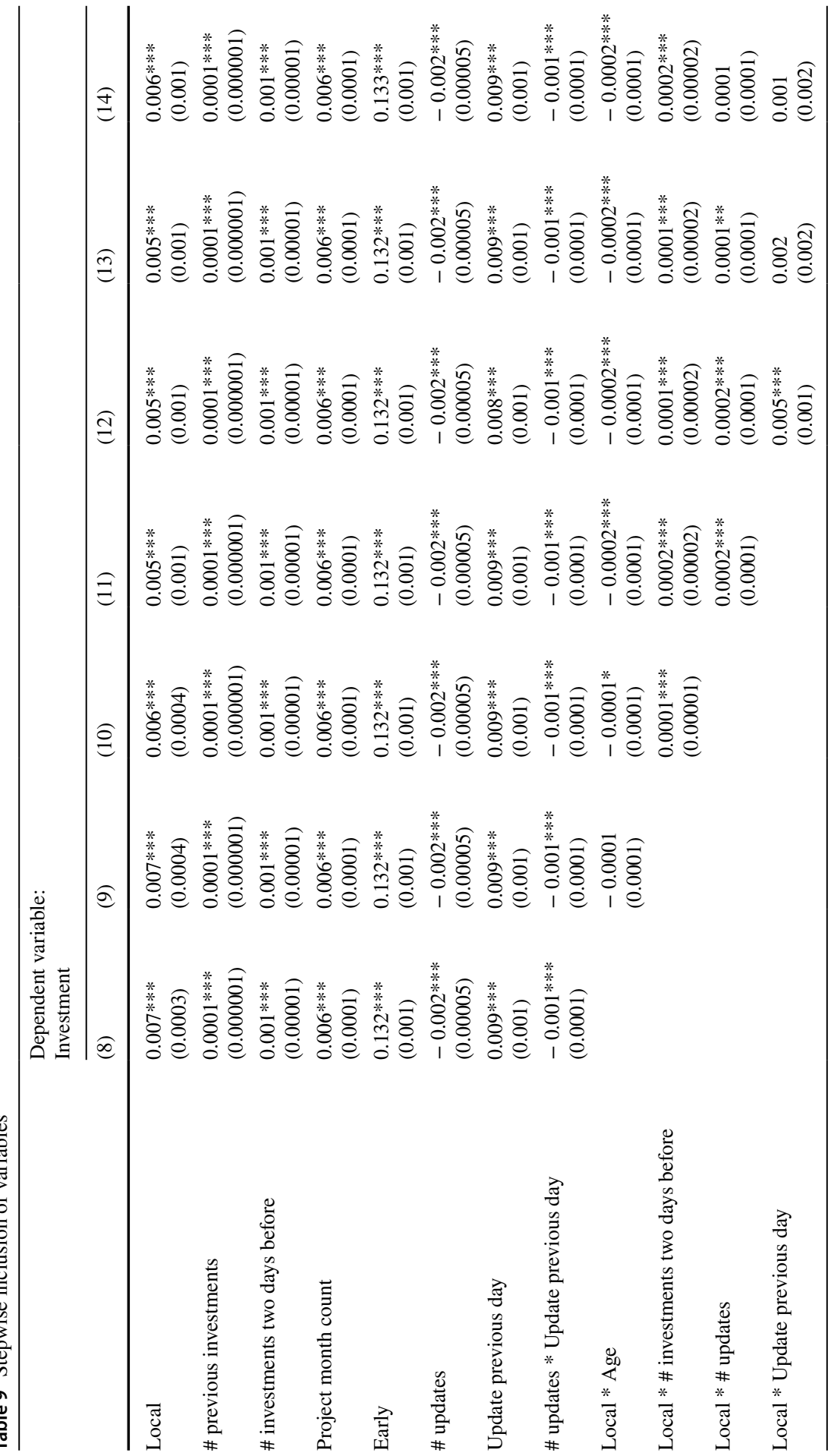




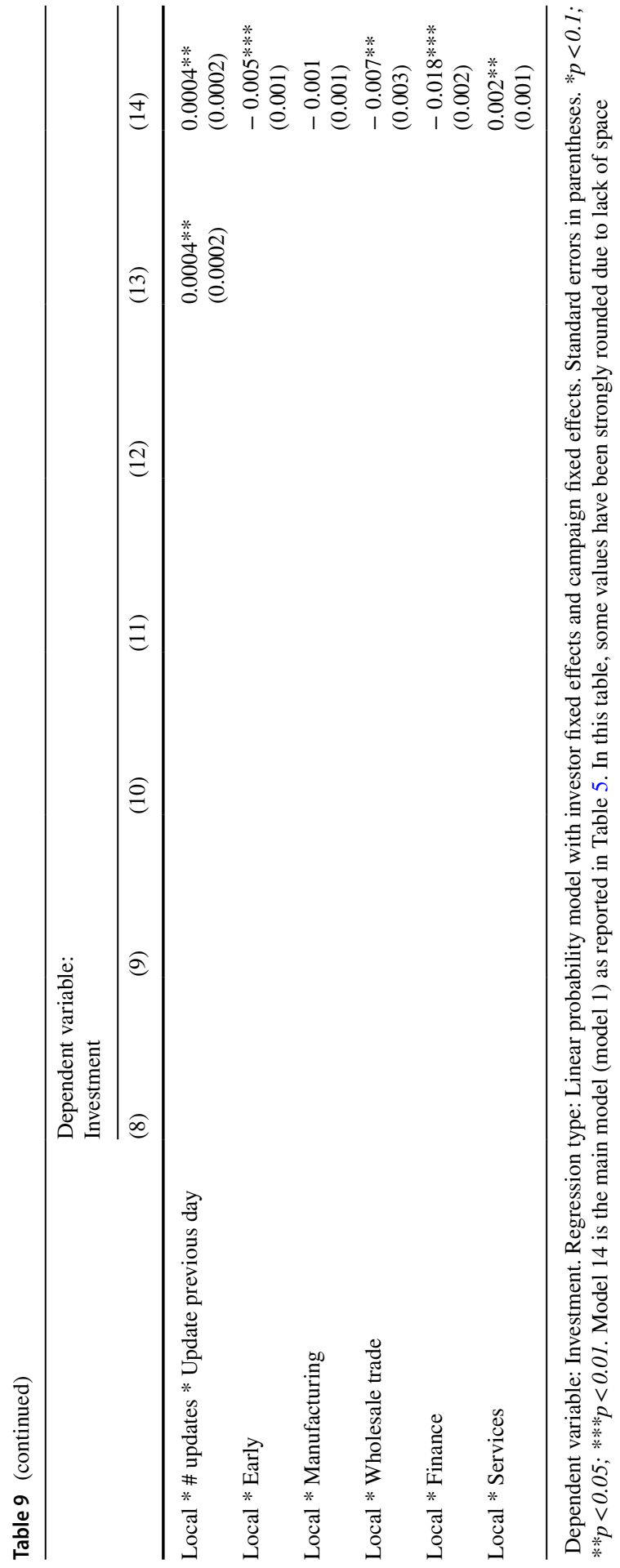


Funding Open Access funding enabled and organized by Projekt DEAL.

Open Access This article is licensed under a Creative Commons Attribution 4.0 International License, which permits use, sharing, adaptation, distribution and reproduction in any medium or format, as long as you give appropriate credit to the original author(s) and the source, provide a link to the Creative Commons licence, and indicate if changes were made. The images or other third party material in this article are included in the article's Creative Commons licence, unless indicated otherwise in a credit line to the material. If material is not included in the article's Creative Commons licence and your intended use is not permitted by statutory regulation or exceeds the permitted use, you will need to obtain permission directly from the copyright holder. To view a copy of this licence, visit http://creativecommons.org/licen ses/by/4.0/.

\section{References}

Agrawal A, Catalini C, Goldfarb A (2014) Some simple economics of crowdfunding. Innov Policy Econ 14:63-97

Agrawal A, Catalini C, Goldfarb A (2015) Crowdfunding: geography, social networks and the timing of investment decisions. J Econ Manage Strat 24:253-274

Ahearne AG, Griever WL, Warnock FE (2004) Information costs and home bias: an analysis of US holdings of foreign equities. J Int Econ 62:313-336

Ahlers GKC, Cumming D, Günther C, Schweizer D (2015) Signaling in equity crowdfunding. Entrep Theory Pract 39:955-980

Åstebro T, Fernández M, Lovo S, Vulkan N (2019) Herding in Equity Crowdfunding (June 18, 2019). Paris December 2018 Finance Meeting EUROFIDAI-AFFI

Baik B, Kang J-K, Kim J-M (2010) Local institutional investors, information asymmetries and equity returns. J Financ Econ 97:81-106

Bandura A (1977) Social Learning Theory. Pentice Hall, New Jersey

Banerjee AV (1992) A simple model of herd behavior. Q J Econ 107:797-817

Belleflamme P, Lambert T, Schwienbacher A (2014) Crowdfunding: Tapping the Right Crowd. J Bus Ventur 29:585-609

Bikhchandani S, Hirshleifer D, Welch I (1992) A theory of fads, fashion, custom and cultural change as informational cascades. J Politic Econ 100:992-1026

Bikhchandani S, Sharma S (2001) Herd ehaviour in financial markets. IMF Staff Papers 47:279-310

Block J, Hornuf L, Schwienbacher A (2018) Which updates during an equity crowdfunding campaign increase crowd participation? Small Bus Econ 50:3-27

Bretschneider U, Leimeister JM (2017) Not just an ego trip: exploring backers' motivation for funding in incentive-based crowdfunding. J Strat Info Syst 26:246-260

Burtch G (2011) Herding behaviour as a network externality. In: thirty second international conference information systems (Shanghai)

Burtch G, Ghose A, Wattal S (2013) An empirical examination of the antecedents and consequences of investment patterns in crowd-funded markets. Info Syst Res 24:499-519

Butler AW (2008) Distance still matters: Evidence from municipal bond underwriting. Review Financ Stud 21:763-784

Chakraborty S, Swinney R (2020) Signaling to the crowd: private quality information and rewards-based crowdfunding. Manufact Service Oper Manage Forthcom 84:41

Cohen J (1988) Statistical power analysis for the behavioral Sciences, 2nd edn. Erlbaum, Hillsdale

Colombo MG, Franzoni C, Rossi-Lamastra C (2015) Internal social capital and the attraction of early contributions in crowdfunding. Entrep Theory Pract 39:75-100

Cooper I, Kaplanis E (1994) The implications of the home bias in equity portfolios. Bus Strat Rev 5:41-53

Cornaggia JN, Cornaggia KJ, Israelsen RD (2020) Where the heart is: information production and the home bias. Manage Sci Forthcom 30:66

Coval JD, Moskowitz TJ (1999) Home bias at home: local equity preference in domestic portfolios. J Fin 54:2045-2073 
Coval JD, Moskowitz TJ (2001) The geography of investment: Informed trading and asset prices. J Politic Econ 4:811-841

Devenow A, Welch I (1996) Rational herding in financial economics. Eur Econ Rev 40:603-615

Disdier A-D, Head K (2008) The puzzling persistence of the distance effect on bilateral trade. Rev Econ Stat 90:37-48

Dziuda W, Mondria J (2012) Asymmetric information, portfolio managers and home bias. Rev Financ Stud 25:2109-2154

Fidora M, Fratzscher M, Thimann C (2007) Home bias in global bond and equity markets: the role of real exchange rate volatility. J Int Money Financ 26:631-655

Franke N, von Hippel E, Schreier M (2006) Finding commercially attractive user innovations: a test of leaduser theory. J Prod Innov Manag 23:301-315

French KR, Poterba JM (1991) Investor diversification and international equity markets. Am Econ Rev 81:222-226

Gabaix X, Laibson D (2003) Bounded rationality and directed cognition. Unpublished working paper. MIT and Harvard University

Gabaix X, Laibson D, Moloche G Weinberg S (2003) The allocation of attention: theory and evidence. Unpublished working paper. MIT and Harvard University

Graham J, Harvey C, Huang H (2009) Investor competence, trading frequency and home bias. Manage Sci 55:1094-1106

Grinblatt M, Keloharju M (2001) How distance, language and culture influence stockholdings and trades. J Financ 56:1053-1073

Guenther C, Johan S, Schweizer D (2018) Is the crowd sensitive to distance? - how investment decisions differ by investor type. Small Bus Econ 50:289-305

Heath C, Tversky A (1991) Preference and belief: ambiguity and competence in choice under uncertainty. J Risk Uncertain 4:5-28

Hemer J (2011) A snapshot on crowdfunding. Arbeitspapiere unternehmen und region no. R2/2011

Hillberry R, Hummels D (2003) Intra-national home bias: some explanations. Rev Econ Stat 85:1089-1092

Hornuf L, Neuenkirch M (2017) Pricing shares in equity crowdfunding. Small Bus Econ 48:795-811

Hornuf L, Schmitt M Stenzhorn E (2020) Does a local bias exist in equity crowdfunding? max planck institute for innovation \& competition research paper No. 16-07, CESifo working paper No. 8154

Hornuf L, Schwienbacher A (2018) Market mechanisms and funding dynamics in equity crowdfunding. J Corp Financ 50:556-574

Hortaçsu A, Martínez-Jerez F, Douglas J (2009) The geography of trade in online transactions: Evidence from eBay and mercadolibre. Am Econ J Microecon 1:53-74

Hubermann G (2001) Familiarity breeds investment. Rev Financ Stud 14:659-680

Ivković Z, Weisbenner S (2005) Local does as local is: information content of the geography of individual investors' common stock investments. J Financ 60:267-306

Jeske K (2001) Equity home bias: can information cost explain the puzzle? Econ Rev 86:31-42

Kahneman D (1973) Attention and effort. Prentice hall, New Jersey

Karlsson A, Nordén L (2007) Home sweet home: home bias and international diversification among individual investors. J Bank Financ 31:317-333

Kilka M, Weber M (2000) Home Bias in International Stock Return Expectations. Journal of Psychology and Financial Markets 1:176-192

Kim JH, Newberry P, Qiu C (2015) An empirical analysis of a crowdfunding platform. NET institute working paper No. $15-12$

Kimball M, Shumway T (2006) Investor sophistication and the participation, home bias, diversification and employer stock puzzles. Unpublished manuscript, University of Michigan

Kumar M (1988) World geodetic system 1984: a modern and accurate global reference frame. Mar Geodesy 12:117-126

Kuppuswamy V, Bayus BL (2013) Crowdfunding creative ideas: the dynamics of project backers. In: Cumming D, Hornuf L (eds) The Economics of crowdfunding. Palgrave Macmillan, London

Kuppuswamy V, Bayus BL (2017) Does my contribution to your crowdfunding project matter? J Bus Ventur 32:72-89

Lai S, Teo M (2008) Home biased analysts in emerging markets. J Financ Quant Anal 43:685-716

Lee E, Lee B (2012) Herding ehaviour in online P2P lending: an empirical investigation. Electron Commer Res Appl 11:495-503

Lewis K (1999) Trying to explain home bias in equities and consumption. J Econ Lit 37:571-608 
Lin M, Viswanathan S (2016) Home bias in online investments: an empirical study of an online crowdfunding market. Manage Sci 62:1393-1414

Lin M, Prabhala NR, Viswanathan S (2013) Judging borrowers by the company they keep: friendship networks and information asymmetry in online peer-to-peer lending. Manage Sci 59:17-35

Lu C-W, Chen T-K, Liao H-H (2010) Information uncertainty, information asymmetry and corporate bond yield spreads. J Bank Financ 34:2265-2279

Malloy CJ (2005) The geography of equity analysis. J Financ 60:719-755

Massa M, Simonov A (2006) Hedging, familiarity and portfolio choice. Rev Financ Stud 19:533-685

Miglo A, Miglo V (2019) Market imperfections and crowdfunding. Small Bus Econ 53:51-79

Miglo A (2020) Crowdfunding Under Market Feedback, Asymmetric Information And Overconfident Entrepreneur. Entrep Res J 28:49-70

Mollick E (2014) The dynamics of crowdfunding: an exploratory study. J Bus Ventur 29:1-16

Mondria J, Wu T (2010) The puzzling evolution of the home bias, information processing and financial openness. J Econ Dyn Control 34:875-896

Moritz A, Block J, Lutz E (2015) Investor communication in equity-based crowdfunding: a qualitativeempirical study. Qualit Res Financ Mark 7:309-342

Morse A, Shive S (2011) Patriotism in your portfolio. J Financ Mark 14:411-440

Nguyen T, Cox J, Rich J (2019) Invest or regret? An empirical investigation into funding dynamics during the final days of equity crowdfunding campaigns. J Corp Financ 58:784-803

Peng L, Xiong W (2006) Investor attention, overconfidence and category learning. J Financ Econ 80:563-602

Pradkhan E (2016) Impact of culture and patriotism on home bias in bond portfolios. RMS 10:265-301

Sims C (2003) Implications of Rational Inattention. J Monetary Econ 50:665-690

Spence M (1973) Job market signaling. Quart J Econ 87:355-374

Spence M (2002) Signaling in retrospect and the informational structure of markets. Am Econ Rev 92:434-549

Statista. 2020. Equity-based crowdfunding transaction value in Europe (excluding the UK) from 2013 to 2018 (in million euros). https://www.statista.com/statistics/797673/equity-based-crowdfunding-uk/. Accessed 25 August 2020

Strong N, Xu X (2003) Understanding the equity home bias: evidence from survey data. Rev Econ Stat $85: 307-312$

Stuart T, Sorenson O (2003) The geography of opportunity: spatial heterogeneity in founding rates and the performance of biotechnology firms. Res Policy 32:229-253

Van de Rijt A, Kang SM, Restivo M, Patil A (2014) Field experiments of success-breeds-success dynamics. Proc Natl Acad Sci USA 111:6934-6939

Van Nieuwerburgh S, Veldkamp L (2009) Information immobility and the home bias puzzle. J Financ 64:1187-1215

Vismara S (2018) Information Cascades among Investors in Equity Crowdfunding. Entrep Theory Pract 42:467-497

Vulkan N, Åstebro T, Fernandez M (2016) Equity Crowdfunding: A New Phenomena. J Bus Vent Insights 5:37-49

Walther M, Bade M (2020) Observational learning and willingness to pay in equity crowdfunding. Bus Res 13:639-661

Wolf HC (2000) Intranational home bias in trade. Rev Econ Stat 82:555-563

Xu A, Yang X, Rao H, Fu WT, Huang SW, Bailey BP (2014) Show me the money! An analysis of project updates during crowdfunding campaigns. Proceedings of the $32^{\text {nd }}$ Annual ACM Conference for human factors in computing systems, 591-600

Zaggl MA, Block J (2019) Do small funding amounts lead to reverse herding? A field experiment in rewardbased crowdfunding. J Bus Vent Insights 12:e00139

Zhang J, Liu P (2012) Rational herding in microloan markets. Manage Sci 58:892-912

Publisher's Note Springer Nature remains neutral with regard to jurisdictional claims in published maps and institutional affiliations. 